\title{
The Role of Interleukin-4 VNTR Polymorphism in Dysmenorrhea Development
}

\section{interlökin-4 VNTR Polimorfizminin Dismenore Gelişimindeki Rolü}

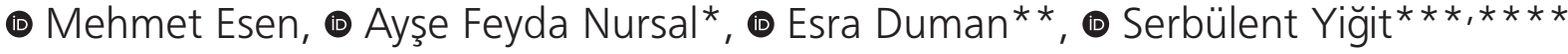 \\ Gaziosmanpaşa University Faculty of Medicine, Department of Emergency Medicine, Tokat, Turkey \\ *Hitit University Faculty of Medicine, Department of Medical Genetics, Çorum, Turkey \\ **Gaziosmanpaşa University Faculty of Medicine, Department of Experimental Medicine, Tokat, Turkey \\ ***Gaziosmanpaşa University Faculty of Medicine, Department of Medical Biology, Tokat, Turkey \\ $* * * *$ Ondokuz Mayıs University Faculty of Veterinary, Department of Veterinary Genetics, Samsun, Turkey
}

Abstract

\begin{abstract}
Aim: Primary dysmenorrhea (PD) is among the most common gynecological diseases in young women presenting to emergency department. It has been shown that cytokines played roles in PD pathogenesis. Interleukin-4 (IL-4), a cytokine, regulates multiple biological functions. The objective of the present study was to examine possible relationship between $I L-4$ variable number of tandem repeat (VNTR) polymorphism and susceptibility to PD.
\end{abstract}

Methods: This study was based on a prospective cohort study design. A total of 120 patients with PD and 116 healthy controls, who presented to the emergency department between 01.12.2018 and 01.12.2019, were included in the study. IL-4 VNTR was genotyped by polymerase chain reaction (PCR). The results of the analyses were evaluated in terms of statistically significant differences.

Results: The prevalence of genotypes of P1/P1, P1/P2, and P2/ P2 for IL-4 VNTR were $1.72 \%, 34.4 \%$, and $63.7 \%$ in patients with $\mathrm{PD}$, and $0.8 \%, 26.6 \%$, and $72.5 \%$ in controls, respectively. There was no significant difference in distribution of genotypes and allele frequencies of IL-4 VNTR between the groups ( $p>0.05)$.

Conclusion: This research is the first study to examine the relationship between IL-4 VNTR and PD. The data of the present study did not support a relationship between IL-4 VNTR and PD risk.

Keywords: Dysmenorrhea, interleukin-4, VNTR, PCR
Amaç: Primer dismenore (PD), acil servise kabul edilen genç kadınlarda en sık görülen jinekolojik hastalıklar arasındadır. Bazı sonuçlar sitokinlerin PD patogenezinde rol oynadığını göstermiştir. Bir sitokin olan interlökin-4 (IL-4), birçok biyolojik fonksiyonları düzenler. Bu çalışmanın amacı, IL-4 değişken ardışık tekrar sayılı (VNTR) varyantı ile PD'ye yatkınlık arasındaki olası ilişkiyi incelemektir.

Yöntemler: Bu çalışma prospektif bir kohort çalışma tasarımına dayanmaktadır. Acil Servis'e 01.12.2018-01.12.2019 tarihleri arasında başvuran toplam 120 PD hastası ve 116 sağlıklı kontrol çalışmaya dahil edildi. IL-4 VNTR varyantının genotiplemesi polimeraz zincir reaksiyonu (PZR) analizi ile belirlendi. Analiz sonuçları istatistiksel olarak anlamlı farklılıklar açısından değerlendirildi.

Bulgular: IL-4 VNTR varyantı için P1/P1, P1/P2 ve $P 2 / P 2$ genotiplerinin prevalansı sırasıyla PD hastalarında $\% 1,72, \% 34,4$ ve $\% 63,7$ ve kontrol grubunda $\% 0,8, \% 26,6, \% 72,5$ idi. IL-4 VNTR varyantının genotiplerinin dağılımı ve alel frekansları gruplar arasında anlamlı düzeyde farklılık göstermedi.

Sonuç: Bu araştırma IL-4 VNTR ve dismenore arasındaki ilişkiyi inceleyen ilk çalışmadır. Bu çalışmanın verileri, IL-4 VNTR varyantı ile PD riski arasındaki ilişkiyi desteklememiştir.

Anahtar Sözcükler: Dismenore, interlökin-4, VNTR, PZR

\section{Introduction}

Dysmenorrhea, painful cramps of uterine origin during menstrual periods (1), is the major cause of emergency department visits in reproductive-age women regardless of age, race, nationality, and socioeconomic status. It is classified as primary dysmenorrhea (PD) (menstrual pain with no organic cause) or secondary dysmenorrhea (menstrual pain due to pelvic disease) (2). The cause of PD is still not clear. Hyperproduction of uterine
Address for Correspondence/Yazışma Adresi: Ayşe Feyda Nursal, Hitit University Faculty of Medicine, Department of Medical Genetics, Çorum, Turkey

Phone: +90 3642221100 E-mail: feyda.nursal@gmail.com ORCID: orcid.org/0000-0001-7639-1122 Received/Geliş Tarihi: 05 May 2020 Accepted/Kabul Tarihi: 23 July 2020
${ }^{\circ}$ Copyright 2020 by The Medical Bulletin of istanbul Haseki Training and Research Hospital The Medical Bulletin of Haseki published by Galenos Yayınevi. ${ }^{8}$ Telif Hakkı 2020 istanbul Haseki Eğitim ve Araştırma Hastanesi Haseki Tıp Bülteni, Galenos Yayınevi tarafından yayınlanmıştır. 
prostaglandin (PG), especially of $\mathrm{PGF}_{2 a}$ and $\mathrm{PGF}_{2}$ is held responsible for the pathophysiology. High levels of these PGs lead to increased uterine tone and high-amplitude myometrial contractions (3). PG synthesis is regulated by progesterone; when progesterone is low, as in right before the menstruation, PG levels rise (3). It has been demonstrated that PGs are involved in variety of biological actions both physiological and pathological such as pain, inflammation, body temperature, and sleep regulation (3). Strömberg et al. (4) reported, markedly higher plasma vasopressin and PGF2 $\alpha$ metabolite levels on the first day of menstruation in women with severe PD. In their study including 43 women with dysmenorrhea and 51 controls, Yeh et al. (5) found that plasma oxytocin and interleukin-6 (IL-6) levels were significantly higher in patients with dysmenorrhea than in controls. Uterine contractility might be increased by these mediators playing important roles in PD pathophysiology (6).

Interleukin-4 (IL-4), a cytokine with several biological functions, is secreted chiefly by activated $T$ cells and monocytes, basophilic granulocyte, and mast cells (7). It is the first discovered B-cell pleiotropic cytokine induces proliferation of $T$ cells and antibody synthesis in B cells and has a significant role in immune system (8). The third intron of the IL-4 gene has variable number of tandem repeats (VNTR) polymorphism with $70 \mathrm{bp}$ occurring as 2 to 4 repeats. The most frequent IL- 4 VNTR allelic form has three repeats (allele 1 ), whilst there is a less common allele that has two repeats (allele 2), and a rarer allele with four repeats (allele 3) (9). Several studies have reported a link between VNTR P1 allele and inflammatory diseases (10).

Given possible defect in IL-4 function in PD, it was decided to examine the IL-4 VNTR polymorphism in patients with PD.

\section{Methods}

\section{Study Population}

Protocols of the study were in line with the principles of the Declaration of Helsinki. The present study was approved by Gaziosmanpaşa University, Medical Faculty (approval no: 18-KAEK-260). The study sample included unrelated female patients with the clinical diagnosis of PD admitted to the Emergency Medicine Department of Gaziosmanpaşa University Research Hospital. Patients with menstrual cycles lasting 21-35 days and menstrual period lasting 3-7-day, who experienced painful menstruations in the past five years with pain starting 1 day prior to or on the menstruation day, were enrolled in the study. Gynecological exam revealed no pathology, no gastrointestinal, gynecologic, or autoimmune diseases, and previous pelvic operation. Unrelated healthy women with no gynecological pathologies found in annual gynecologic examination were included in the study. They had no regularly used drugs (i.e. nonsteroidal antiinflammatory drugs/oral contraceptives). The patients and healthy controls were Turkish, living in the Black Sea region of Turkey. All participants gave informed written consent before participating in the study.

\section{Confounders}

A clinical data collection form was created, and age, age at menarche, marital status, family history of dysmenorrhea, children, smoking status, alcohol consumption, history of rheumatoid arthritis (RA), familial Mediterranean fever, arthralgia and lumbar pain, effect of dysmenorrhea on school performance, oral drug use, intramuscular medication use and Life Satisfaction Scale score were recorded. Life satisfaction refers to as a person's subjective, global evaluation of the positivity of his/her life as a whole or with specific domains of life (e.g. family life, school experiences). The Life Satisfaction Scale is used extensively as a measure of life satisfaction component of subjective well-being with a minimum score of 3 and maximum 8; the lower score indicates lower life satisfaction.

\section{Genotyping}

Genomic DNAs from whole blood of patients and the control group taken with standard procedures (SigmaAldrich, St. Louis, MI, USA) were kept at $-20{ }^{\circ} \mathrm{C}$. Analyses on VNTR polymorphism of IL-4 were made in line with previously described protocols (9). A $25 \mu \mathrm{L}$ reaction mixture with $50 \mathrm{ng}$ DNA, $0.8 \mu \mathrm{M}$ of primers, $200 \mu \mathrm{M}$ of each dNTP, $2.5 \mathrm{mMMgCl}, 1.5$ units of Taq polymerase, and 2.5 $\mu \mathrm{L} 10 \times \mathrm{KCl}$ buffer were used for polymerase chain reaction (PCR). Forward 5' AGG CTG AAA GGG GGA AAG C3' and reverse $5^{\prime}$-CTG TTC ACC TCA ACT GCT CC-3' primers were used for amplification in the first denaturation at 95 ${ }^{\circ} \mathrm{C}$ for 5 minutes, 30 denaturation cycles at $94{ }^{\circ} \mathrm{C}$ for 30 $\mathrm{s}$, annealing at $58{ }^{\circ} \mathrm{C}$ for $45 \mathrm{~s}$, extension at $72{ }^{\circ} \mathrm{C}$ for 1 minute, and the last extension at $72{ }^{\circ} \mathrm{C}$ for 10 minutes. The separation of PCR products was carried out with $3 \%$ agarose gel, and visualization was carried out with ethidium bromide staining. PCR products were $183 \mathrm{bp}$ for P1 allele, and 253 bp for P2 allele.

\section{Statistical Analysis}

The Statistical Package for the Social Sciences (IBM SPSS, version 20), and OpenEpi Info package v 3.01 (www.openepi.com) were used for statistical analyses. All data were expressed as mean \pm standard deviation. The relationships between IL-4 VNTR polymorphism and clinical and demographical characteristics of patients were analyzed with $\chi^{2}$ test, Fisher's exact test, or ANOVA test. To evaluate risk factors, Odds ratios (ORs) and 95\% confidence intervals $(\mathrm{Cls})$ were employed. All $\mathrm{p}$ values 
were binary. A $p$ value of less than 0.05 was considered statistically significant. Additionally, Search Tool for the Retrieval of Interacting Genes/Proteins (STRING) analysis was added (Figure 1).

\section{Results}

A total of 236 subjects [120 PD females (mean age: $25.64 \pm 4.24$ years) and 116 healthy females (mean age: $25.76 \pm 4.23$ years)] were genotyped for IL-4 VNTR polymrphism. Baseline clinical and demographic features of the patient and control groups are given in Table 1.

The IL-4 VNTR polymorphism genotype and allele frequency distribution in study and control groups is given in Table 2. The 3 IL-4 genotypes were classified as: P1/P1 (183 bp), P2/P2 (253 bp) and P1/P2 (183 and 253 bp fragments). The frequencies of P1/P1, P1/P2, and P2/ P2 genotypes of VNTR variant in patients were $1.72 \%$,

\begin{tabular}{|c|c|c|}
\hline Characteristics & $\begin{array}{l}\text { Control group } \\
(\mathrm{n}=116)(\%)\end{array}$ & $\begin{array}{l}\text { Patient group } \\
(\mathrm{n}=120)(\%)\end{array}$ \\
\hline Age, mean $\pm S D$, years & $25.76 \pm 4.23$ & $25.64 \pm 4.24$ \\
\hline Menarche age & - & $12.28 \pm 0.63$ \\
\hline Marital status, yes/no, n (\%) & - & $50 / 66(43.1 / 56.9)$ \\
\hline Family history, yes/no, n (\%) & - & $50 / 66(43.1 / 56.9)$ \\
\hline \multicolumn{3}{|l|}{ Children, n (\%) } \\
\hline $0, \mathrm{n}(\%)$ & - & $80(69.0)$ \\
\hline $1, n(\%)$ & - & $11(9.5)$ \\
\hline $2, n(\%)$ & - & $19(16.4)$ \\
\hline $3, \mathrm{n}(\%)$ & - & $6(5.2)$ \\
\hline Smoking, yes/no, n (\%) & - & $10 / 106(8.6 / 91.4)$ \\
\hline Alcohol, yes/no, n (\%) & - & $3 / 113(2.6 / 97.4)$ \\
\hline RA history yes/no, n (\%) & - & $2 / 114(1.7 / 98.3)$ \\
\hline FMF history, yes/no, n (\%) & - & $4 / 112(3.4 / 96.6)$ \\
\hline Arthralgia, yes/no, n (\%) & - & $2 / 114(1.7 / 98.3)$ \\
\hline Lumbar pain, yes/no, n (\%) & - & $8 / 108(6.9 / 93.1)$ \\
\hline School effect, yes/no, n (\%) & - & $\begin{array}{l}12 / 104 \\
(10.3 / 89.7)\end{array}$ \\
\hline Oral drug use, yes/no, n (\%) & - & $\begin{array}{l}103 / 13 \\
(88.8 / 11.2)\end{array}$ \\
\hline $\begin{array}{l}\text { IM medication use, yes/no, } \\
\text { n (\%) }\end{array}$ & - & $\begin{array}{l}13 / 103 \\
(11.2 / 88.8)\end{array}$ \\
\hline Life Satisfaction Score, n (\%) & - & $11 / 121(8.3 / 91.7)$ \\
\hline $3, \mathrm{n}(\%)$ & - & $2(1.7)$ \\
\hline $4, n(\%)$ & - & $4(3.4)$ \\
\hline $5, \mathrm{n}(\%)$ & - & $4(3.4)$ \\
\hline $6, n(\%)$ & - & $6(5.2)$ \\
\hline $7, \mathrm{n}(\%)$ & - & $79(68.1)$ \\
\hline $8, \mathrm{n}(\%)$ & - & $21(18.1)$ \\
\hline
\end{tabular}

$34.4 \%$, and $63.7 \%$ and in controls were $0.8 \%, 26.6 \%$, and $72.5 \%$, respectively. The distribution of genotype of IL-4 VNTR polymorphism was not statistically different between PD patient and control groups ( $p>0.05)$. P1 and P2 allele frequencies were; $18.9 \%$ and $81.0 \%$ in patient group, respectively; and $14.1 \%$ and $85.8 \%$ in the control group, respectively. There was no significant difference in the allele frequencies of IL-4 VNTR between the study and control groups ( $p>0.05$, OR: 0.705, Cl 95\%: 0.431.15).

The STRING database collects scores and integrates all publicly available sources of protein-protein interaction information. Analyzing the IL-4 protein with STRING database, predicted the functional partners of the protein with high confidence (score: 0.7) as: IL-6, TNF, IL1-B, CXCL8, IL-4R, CCL2, IL-18, IL-13RA1, STAT6, IL-2RG. Figure 1 shows the interaction network of these proteins.

\section{Discussion}

Menstruation is a physiological event that occurs in cycles. Various problems might occur (irregular menstruation, excessive hemorrhage, and dysmenorrhea). Dysmenorrhea is generally defined as severe, painful, cramping sensation in the lower abdomen frequently associated with perspiration, headache, nausea, vomiting, and diarrhea (11). Its worldwide prevalence varies between $28 \%$ and $71.7 \%(12,13)$. In a study conducted with university students in Turkey, the prevalence was found to be $87.7 \%$ (14). There is a scarce number of studies about genetic susceptibility to dysmenorrhea. A study involving monozygotic/dizygotic Australian twins by Treloar et al. (15) showed that genetic factors were responsible for $39 \%$ of longitudinally stable variation in

\begin{tabular}{|c|c|c|c|c|}
\hline IL-4 VNTR & $\begin{array}{l}\text { Patient } \\
\text { group } \\
(\mathrm{n}=116)(\%)\end{array}$ & \begin{tabular}{|l|}
$\begin{array}{l}\text { Control } \\
\text { group } \\
(n=120)(\%)\end{array}$ \\
\end{tabular} & $\mathbf{p}$ & $\begin{array}{l}\text { OR } \\
\text { (Cl 95\%) }\end{array}$ \\
\hline \multicolumn{5}{|l|}{ Genotypes } \\
\hline P1/P1 & $2(1.72)$ & $1(0.8)$ & \multirow{3}{*}{$>0.05$} & \\
\hline $\mathrm{P} 1 / \mathrm{P} 2$ & $40(34.4)$ & $32(26.6)$ & & \\
\hline $\mathrm{P} 2 / \mathrm{P} 2$ & $74(63.7)$ & $87(72.5)$ & & \\
\hline $\mathrm{P} 1 / \mathrm{P} 1+\mathrm{P} 1 / \mathrm{P} 2: \mathrm{P} 2 / \mathrm{P} 2$ & $42: 74$ & $33: 87$ & $>0.05$ & $\begin{array}{l}0.669 \\
(0.38-1.16)\end{array}$ \\
\hline $\mathrm{P} 1 / \mathrm{P} 1: \mathrm{P} 1 / \mathrm{P} 2+\mathrm{P} 1 / \mathrm{P} 2$ & $2: 114$ & $1: 119$ & $>0.05$ & $\begin{array}{l}0.480 \\
(0.01-6.38)\end{array}$ \\
\hline \multicolumn{5}{|l|}{ Alleles } \\
\hline P1 & 44 (18.9) & $34(14.1)$ & \multirow{2}{*}{$>0.05$} & \multirow{2}{*}{$\begin{array}{l}0.705 \\
(0.43-1.15)\end{array}$} \\
\hline P2 & $188(81.0)$ & $206(85.8)$ & & \\
\hline \multicolumn{5}{|c|}{$\begin{array}{l}\text { IL-4: Interleukin-4, OR: Odds ratio, Cl: Confidence interval, n: Number, VNTR: } \\
\text { Variable number of tandem repeats } \\
\text { Data were analyzed by Fischer exact or } \chi^{2} \text { test }\end{array}$} \\
\hline
\end{tabular}




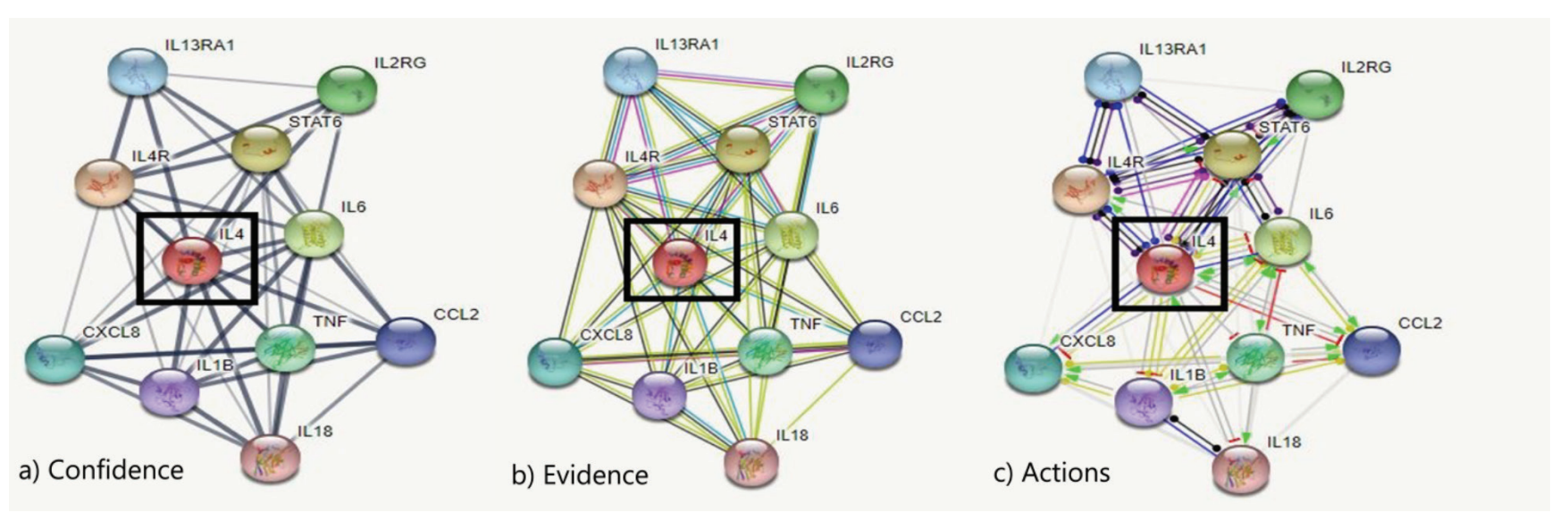

Figure 1. Interactions of IL-4 protein, according to STRING data base predictions:

a) Confidence network: stronger associations are represented by thickerlines, weak associations are represented by thinlines b) This network represents the types of evidences for the association c) Presentation of the different modes of action, involving in the proteinprotein interactions.

IL-4 protein is evidenced with a square, STRING v11: protein-protein association networks with increased coverage, supporting functional discovery in genome-wide experimental datasets.

IL-4: Interleukin-4, STRING: Search Tool for the Retrieval of Interacting Genes/Proteins

menstrual flow, 55\% for pain, and $77 \%$ for perceived limitations.

Pre-clinical studies assume that PG-dependent events induce dysmenorrhea in most women. The onset of menstruation is associated with simultaneous reduction in circulating progesterone and estradiol levels, promoting increased transcription of endometrial collagenase, matrix metalloproteinase, and inflammatory cytokines (16). Peripheral blood analysis in dysmenorrheal women showed extravagant production and levels of oxytocin, PGF2 $\alpha$, vasopressin and IL-6 $(4,5,17,18)$. PGs are important inflammation mediators. Along with its role as a vasodilator, it has been reported that PGE2 synergizes with IL-8 (19), and that progesterone withdrawal, hypoxia, and PGE2 modulate endometrial IL-8 by acting through HIF-1 and NF-kB (20). Menstruation can be considered an inflammatory process manifested by tissue demolition and involvement of inflammatory cells. What is more, there is a significant increase in leukocytes, especially in neutrophils, uNK cells and macrophages in the endometrium where they constitute maximum $40 \%$ of stromal cells just before menstruation (21).

IL-4, a pleotropic cytokine encoded by a gene found on the long arm of chromosome 5, is believed to be important for Th2 responses because it controls the differentiation of precursor $\mathrm{T}$ helper cells into Th2 subset mediating humoral immunity and modulate antibody generation. Besides, IL-4 hinders the synthesis of the proinflammatory cytokines including TNF- $\alpha$, IL- 6 and $\mathrm{IL}-1 \alpha$ and destructive enzymes by monocytes and this emphasizes its strong anti-inflammatory effect (22). There are VNTRs in cytokine genes and various single nucleotide polymorphisms that could have impact on genetic predisposition to some disorders and carcinomas. The 70-base-pair (bp) VNTR variant in the third intron of the IL-4 gene may modify the expression level of this gene, with P1 allele increasing IL-4 expression compared to P2 allele (9). Studies on the relationship between VNTR variant of $I L-4$ gene have been conducted in different populations having several different morbidities with contradictory outcomes. Numerous research have reported the relationship IL-4 VNTR polymorphism with immunologic diseases such as RA (23), systemic lupus erythematosus (24), vitiligo (25), multiple sclerosis (26), alopecia areata (27), and recurrent aphthous stomatitis (28). There are some studies suggesting a relationship between dysmenorrhea and inflammation. In their study, Ma et al. (6) suggested that underlying inflammatory responses vary in patients with dysmenorrhea even in the lack of pain, which may be an etiological factor in dysmenorrhea. Dogru et al. (29) assessed the relationship of MIF-173 and TNF-308 genetic variants with clinical characteristics of PD. They found a statistically significant relationship between gene MIF-173G/C polymorphism and age at menarche and history of back pain in patients with dysmenorrheal $(p=0.003$ and $p=0.042$, respectively). Furthermore, they reported that genotype and allele frequencies of TNF-308G/A polymorphism were significantly different between dysmenorrhea patients and controls ( $p=0.023$ and $p=0.009$, respectively). Erten 
et al. (30) reported that there was a significant increase in MEFV gene mutation frequency in dysmenorrhea patients compared with controls. MEFV gene encodes a protein, pyrin, involving in inflammatory response (31). However, Ozsoy et al. (32) suggested that there was no significant association between IL- 6 gene promoter $-572 \mathrm{G} / \mathrm{C}$ and -597G/A polymorphisms and PD.

The study aimed to determine the relationship between 70-bp VNTR variant of intron-3 of IL-4 gene and PD development. It was found that all subjects included had two alleles (P1 and P2). No significant differences were detected in terms of genotype and allele frequencies in IL-4 VNTR polymorphism between the groups.

\section{Study Limitations}

This study has several limitations. One of the limitations of our study is the relatively small sample size. The population studied consisted of only Turkish subjects. Due to interethnic variability, further studies on other ethnic populations are needed for validation of our findings.

\section{Conclusion}

Dysmenorrhea is a common problem among young women. Our results suggest that IL-4 VNTR polymorphism does not contribute to the PD etiopathogenesis. Unexplained mechanisms and multiple factors involved in the pathogenesis of PD necessitate further studies on this issue.

\section{Authorship Contributions}

Concept: A.F.N., S.Y. Design: S.Y., M.E. Data Collection or Processing: M.E. Analysis or Interpretation: S.Y., E.D. Literature Search: A.F.N., S.Y. Writing: A.F.N.

Conflict of Interest: The authors declared no conflicts of interest concerning the authorship and publication of this article.

Financial Disclosure: The authors declared that this study received no financial support.

\section{References}

1. Kafaei Atrian M, Abbaszadeh F, Sarvieh M, Sarafraz N, Asghari Jafarabadi M. Investigatingthe effect of pressure on third liver point on primary dysmenorrhea: a randomized controlled clinical trial. Iran Red Crescent Med J 2013;15:848-53.

2. Barcikowska Z, Rajkowska-Labon E, Grzybowska ME, Hansdorfer-Korzon R, Zorena K. Inflammatory Markers in Dysmenorrhea and Therapeutic Options. Int J Environ Res Public Health 2020;17:1191.

3. Iacovides S, Avidon I, Baker FC. What we know about primary dysmenorrhea today: a critical review. Hum Reprod Update 2015;21:762-78.

4. Strömberg P, Akerlund M, Forsling ML, Granström E, Kindahl $\mathrm{H}$. Vasopressin and prostaglandins in premenstrual pain and primary dysmenorrhea. Acta Obstet Gynecol Scand 1984;63:533-8.

5. Yeh ML, Chen HH, So EC, Liu CF. A study of serum malondialdehyde and interleukin-6 levels in young women with dysmenorrhea in Taiwan. Life Sci 2004;75:669-73.

6. Ma H, Hong M, Duan J, et al. Altered cytokine gene expression in peripheral blood monocytes across the menstrual cycle in primary dysmenorrhea: a case-control study. PLoS One 2013;8:e55200.

7. Heeb LEM, Egholm C, Boyman O. Evolution and function of interleukin-4 receptor signaling in adaptive immunity and neutrophils. Genes Immun 2020;21:143-9.

8. Hussein YM, El-Shal AS, Rezk NA, Abdel Galil SM, Alzahrani SS. Influence of interleukin-4 gene polymorphisms and interleukin-4 serum level on susceptibility and severity of rheumatoid arthritis in Egyptian population. Cytokine 2013;61:849-55.

9. Mout R, Willemze R, Landegent JE. Repeat polymorphisms in the interleukin-4 gene (IL-4). Nucleic Acids Res 1991;19:3763.

10. Kok YY, Ong HH, Say YH. Interleukin-1 Receptor Antagonist and Interleukin-4 Genes Variable Number Tandem Repeats Are Associated with Adiposity in Malaysian Subjects. J Obes 2017;2017:4104137.

11. Al-Matouq S, Al-Mutairi H, Al-Mutairi O, et al. Dysmenorrhea among high-school students and its associated factors in Kuwait. BMC Pediatr 2019;19:80.

12. Burnett MA, Antao V, Black $A$, et al. Prevalence of primary dysmenorrhea in Canada. J Obstet Gynaecol Can 2005;27:765-70.

13. Pitts MK, Ferris JA, Smith AMA, Shelley JM, Richters J. Prevalence and correlates of three types of pelvic pain in a nationally representative sample of Australian women. Med J Aust 2008;189:138-43.

14. Midilli TS, Yasar E, Baysal E. Dysmenorrhea characteristics of female Students of health school and affecting factors and their knowledge and use of complementary and alternative medicine methods. Holist Nurs Pract 2015;29:194-204.

15. Treloar SA, Martin NG, Heath AC. Longitudinal genetic analysis of menstrual flow, pain, and limitation in a sample of Australian twins. Behav Genet 1998;28:107-16.

16. Oladosu FA, Tu FF, Hellman KM. Nonsteroidal antiinflammatory drug resistance in dysmenorrhea: epidemiology, causes, and treatment. Am J Obstet Gynecol 2018;218:390-400.

17. Liedman R, Hansson SR, Howe $D$, et al. Reproductive hormones in plasma over the menstrual cycle in primary dysmenorrhea compared with healthy subjects. Gynecol Endocrinol 2008;24:508-13.

18. Akerlund M. Involvement of oxytocin and vasopressin in the pathophysiology of preterm labor and primary dysmenorrhea. Prog Brain Res 2002;139:359-65. 
19. Colditz IG. Effect of exogenous prostaglandin E2 and actinomycin $D$ on plasma leakage induced by neutrophilactivating peptide-1/interleukin-8. Immunol Cell Biol 1990;68:397-403.

20. Maybin JA, Hirani N, Jabbour HN, Critchley HOD. Novel roles for hypoxia and prostaglandin E2 in the regulation of IL-8 during endometrial repair. Am J Pathol 2011;178:1245-56.

21. Salamonsen LA, Woolley DE. Menstruation: induction by matrix metalloproteinases and inflammatory cells. J Reprod Immunol 1999;44:1-27.

22. Genevay S, Di Giovine FS, Perneger TV, et al. Association of interleukin-4 and interleukin-1B gene variants with Larsen score progression in rheumatoid arthritis. Arthritis Rheum 2002;47:303-9.

23. Cantagrel A, Navaux F, Loubet-Lescoulié $P$, et al. Interleukin1 beta, interleukin-1 receptor antagonist, interleukin-4, and interleukin-10 gene polymorphisms: relationship to occurrence and severity of rheumatoid arthritis. Arthritis Rheum 1999;42:1093-100.

24. Wu MC, Huang CM, Tsai JJP, Chen HY, Tsai FJ. Polymorphisms of the interleukin- 4 gene in chinese patients with systemic lupus erythematosus in Taiwan. Lupus 2003;12:21-5.

25. Imran M, Laddha NC, Dwivedi M, et al. Interleukin-4 genetic variants correlate with its transcript and protein levels in patients with vitiligo. Br J Dermatol 2012;167:314-23.
26. Kantarci OH, Schaefer-Klein JL, Hebrink DD, et al. A population-based study of IL4 polymorphisms in multiple sclerosis. J Neuroimmunol 2003;137:134-9.

27. Kalkan G, Karakus N, Baş $Y$, et al. The association between Interleukin (IL)-4 gene intron 3 VNTR polymorphism and alopecia areata (AA) in Turkish population. Gene 2013;527:565-9.

28. Kalkan G, Yigit S, Karakus N, Baş Y, Seçkin HY. Association between interleukin 4 gene intron 3 VNTR polymorphism and recurrent aphthous stomatitis in a cohort of Turkish patients. Gene 2013;527:207-10.

29. Dogru HY, Ozsoy AZ, Karakus N, Delibas IB, Isguder CK, Yigit S. Association of Genetic Polymorphisms in TNF and MIF Gene with the Risk of Primary Dysmenorrhea. Biochem Genet 2016;54:457-66.

30. Erten S, Altunoglu A, Keskin HL, et al. Increased frequency of MEFV gene mutations in patients with primary dysmenorrhea. Mod Rheumatol 2013;23:959-62.

31. Manukyan G, Aminov R. Update on Pyrin Functions and Mechanisms of Familial Mediterranean Fever. Front Microbiol 2016;7:456.

32. Ozsoy AZ, Karakus N, Yigit S, Cakmak B, Nacar MC, Yılmaz Dogru H. The Evaluation of IL6 and ESR1 Gene Polymorphisms in Primary Dysmenorrhea. Immunol Invest 2016;45:75-86. 